\title{
LEOKADIA OREZZIAK
}

Szkoła Główna Handlowa

ORCID: 0000-0003-0673-899X

\section{Unia bankowa i Europejski Fundusz Walutowy alternatywą dla unii fiskalnej w strefie euro?}

\author{
The banking union and the European Monetary Fund \\ as an alternative to the fiscal union in the Eurozone?
}

The public debt crisis in the Eurozone, which began in 2010, showed serious weaknesses of the structure on which it was based. It was only thanks to extraordinary intervention activities that the situation was stabilised and the risk of the disintegration of this zone was eliminated. Currently, an urgent task for the institutions and member states of the European Union is to develop and implement solutions that would avoid such risks in the future. The aim of the article is to analyse and evaluate the possibilities of deepening integration in the euro area towards fiscal federalism and to examine whether the banking union and the future European Monetary Fund could be alternative solutions to the fiscal union. The analysis leads to a negative answer to this question due to the significant differences between the two projects in terms of their objectives, scopes and potential consequences from the perspective of the participating countries' sovereignty. This analysis also shows that the banking union is an expression of a pragmatic approach to potential threats to the Eurozone's stability in a situation where the establishment of a fiscal union is unlikely in the foreseeable future.

Keywords: euro area, crisis, fiscal union, banking union, capital markets union, European Monetary Fund

Słowa kluczowe: strefa euro, kryzys, unia fiskalna, unia bankowa, unia rynków kapitałowych, Europejski Fundusz Walutowy

\section{Uwagi wstępne}

Globalny kryzys finansowy, który rozpoczął się w 2007 r. w Stanach Zjednoczonych, a następnie rozprzestrzenił na cały świat, przyczynił się do poważnego kryzysu zadłużenia publicznego w strefie euro. Ten z kolei 
ujawnił słabości istniejących w strefie euro rozwiązań, które mają na celu zapewnienie dyscypliny budżetowej w krajach członkowskich oraz gwarantowanie możliwości szybkiego podejmowania adekwatnych działań antykryzysowych przez wspólne instytucje. Problemy finansowe niektórych krajów członkowskich stały się na tyle poważne, że powstało realne zagrożenie rozpadu strefy euro. Ostatecznie udało się je przezwyciężyć dzięki uruchomieniu pomocy finansowej dla krajów najbardziej dotkniętych kryzysem oraz nadzwyczajnym działaniom Europejskiego Banku Centralnego (EBC).

Strefa euro ukształtowana została w ten sposób, że prowadzoną w jej ramach politykę pieniężną określa się i realizuje na szczeblu centralnym przez ponadnarodową instytucję - EBC. Drugi kluczowy element polityki makroekonomicznej, jakim jest polityka budżetowa, ma natomiast charakter zdecentralizowany, gdyż prawo do decydowania o dochodach i wydatkach w ramach finansów publicznych należy do władz państw członkowskich. Zostały one jedynie zobowiązane do przestrzegania ograniczeń dotyczących relacji deficytu budżetowego i długu publicznego do PKB określonych w Traktacie o funkcjonowaniu Unii Europejskiej (TFUE) oraz Pakcie stabilności $i$ wzro$s t u$; w przeciwnym razie muszą się liczyć z podjęciem przez unijne instytucje działań dyscyplinujących, a ostatecznie nawet z nałożeniem kar finansowych. Twórcy strefy euro oczekiwali, że istotną rolę odegrają w niej rynki finansowe, wymuszając na państwach członkowskich dyscyplinę budżetową poprzez konieczność ponoszenia wyższych kosztów zaciągania na rynku pożyczek przez te z nich, które zadłużałyby się nadmiernie.

Doświadczenia związane z kryzysem finansowym i kryzysem zadłużenia publicznego wymusiły przeprowadzenie pewnych zmian w bieżącym zarządzaniu strefą euro, jednak dotychczasowe reformy postrzegane są jako niewystarczające wobec potencjalnych zagrożeń dla jej stabilności. Od dłuższego czasu toczy się debata o niezbędnych zmianach systemowych, które zwiększyłyby odporność strefy na przyszłe kryzysy finansowe i gospodarcze oraz zapewniłyby większe możliwości ich zwalczania. Wśród proponowanych zmian dominują dwa główne kierunki. Pierwszym miałaby być ściślejsza integracja $\mathrm{w}$ ramach strefy euro, prowadząca ostatecznie do unii fiskalnej wraz z odrębnym budżetem. Drugi to dokończenie budowy unii bankowej i ustanowienie Europejskiego Funduszu Walutowego (EFW), co miałoby stanowić alternatywę dla pierwszego kierunku, a przynajmniej pewien etap na tej drodze. 


\section{Federalizm fiskalny w procesie integracji europejskiej}

Zwolennicy unii fiskalnej wskazują, że jest ona konieczna, by zapewnić strefie euro trwałość i stabilność ${ }^{1}$. Miałaby ona stanowić rozwiązanie, w którym państwa członkowskie, poza przestrzeganiem uzgodnionych reguł dotyczących stanu finansów publicznych, ponosiłyby wspólnie ciężary finansowe (risk-sharing). Byłaby to przynajmniej częściowa realizacja idei federalizmu fiskalnego (fiscal federalism), tzn. specyficznego układu relacji finansowych między centralnym szczeblem władzy a szczeblami niższymi, regionalnymi, występującego na ogół w państwie federalnym. Władze centralne dysponują w nim odpowiednio wysokim budżetem, by realizować zadania istotne z punktu widzenia całego organizmu państwowego (np. bezpieczeństwo publiczne, politykę zagraniczną i obronną, redystrybucję dochodów czy stabilizację gospodarki), a władze regionalne zarządzają budżetami pozwalającymi na realizację potrzeb regionów. Federalizm fiskalny stanowi odzwierciedlenie wysokiego poziomu decentralizacji systemu władzy, co oznacza, że uprawnienia szczebla centralnego są stosunkowo ograniczone, a zakres kompetencji szczebli niższych - możliwie szeroki. Władze centralne dysponują odpowiednio silnymi instrumentami finansowymi, by realizować swoje funkcje, np. podatkami, dotacjami czy transferami finansowymi i rzeczowymi na rzecz grup społecznych i regionów. Federalizm fiskalny jest więc sposobem podziału ryzyka między części składowe organizmu federacyjnego ${ }^{2}$.

Kwestię federalizmu fiskalnego żywo dyskutowano na przełomie lat czterdziestych i pięćdziesiątych ubiegłego wieku, przed rozpoczęciem procesu integracji gospodarczej w Europie Zachodniej. Była też dotychczas jednym z głównych zagadnień, które każdorazowo pojawiały się w debatach nad kolejnymi etapami integracji europejskiej. Zwolennicy ściślejszej współpracy wskazywali, że postęp w kierunku federalizmu fiskalnego jest niezbędny, zwłaszcza w procesie tworzenia wspólnej waluty. Opublikowany w $1970 \mathrm{r}$. raport Wernera zawierał propozycje dotyczące etapowej budowy unii gospodarczej i walutowej we Wspólnocie w ciągu dziesięciu lat. Miała ona nie tylko prowadzić scentralizowaną politykę pieniężną, ale też dysponować odrębnym

1 H. Berger, G. Dell'Ariccia, M. Obstfeld, Revisiting the economic case for fiscal union in the euro area, International Monetary Fund, Washington, DC, 21 II 2018.

2 J.R. Brooks, Fiscal federalism as risk-sharing. The insurance role of redistributive taxation, Georgetown University Law Center, 2014, dostępny w internecie [dostęp: 12 XI 2017]: <http://scholarship.law.georgetown.edu/cgi/viewcontent.cgi? article=2357 \&context $=$ facpub $>$. 
budżetem, choć jego wielkość nie została wtedy określona ${ }^{3}$. Realizacja tego projektu załamała się jednak niemal od razu, głównie ze względu na poważny kryzys gospodarczy początku lat siedemdziesiątych. W późniejszym czasie sprawę federalizmu fiskalnego podjęto m.in. w opublikowanym w $1977 \mathrm{r}$. raporcie McDougalla, przygotowanym przez grupę niezależnych ekspertów powołanych przez Komisję Wspólnot Europejskich. Zaproponowano w nim, by w fazie przedfederacyjnej wspólny budżet zwiększył się z 0,7 do 2,5 proc. PKB, a w finalnej, federacyjnej - do 5-7 proc. łącznego PKB państw mających tworzyć unię walutową. Jak zaznaczono w raporcie, byłoby to i tak niezbyt dużo w porównaniu z 20-25 proc. PKB w takich federacjach jak Stany Zjednoczone czy Niemcy ${ }^{4}$.

Trudności w uzyskaniu zgody wszystkich państw członkowskich na zwiększenie wspólnego budżetu nawet do kilku procent PKB spowodowały, że przy następnej próbie ustanowienia unii gospodarczej i walutowej, którą podjęto pod koniec lat osiemdziesiątych, zastosowane zostało bardziej pragmatyczne podejście. Przyjęto wówczas, że wspólną walutę można wprowadzić bez pogłębionej integracji budżetowej czy federalizmu fiskalnego. Założenie to znalazło się w tzw. raporcie Delorsa, tzn. dokumencie przedstawionym w 1989 r. przez grupę ekspertów, którą kierował Jacques Delors, ówczesny przewodniczący Komisji Europejskiej. Zawierał on propozycje konkretnych kroków w celu ustanowienia unii walutowej ${ }^{5}$. Propozycje te stały się podstawą do negocjacji w sprawie Traktatu o Unii Europejskiej w części dotyczącej unii gospodarczej i walutowej (UGW). Silnie wpłynęły też na kształt obecnej strefy euro, która została oparta na założeniu, że prywatne rynki finansowe będą w stanie zastąpić brak wspólnego budżetu i instytucji federalnych. Wspólną walutę, emitowaną przez ponadnarodowy bank centralny, powołano więc do życia, mimo że nie udało się ustanowić unii politycznej, która pozwoliłaby stworzyć odpowiednio duży wspólny budżet. W rezultacie kształ-

3 Report to the Council and the Commission on the realization by stages of economic and monetary union in the Community, Luxembourg, 8 X 1970, dostępny w internecie [dostęp: 6 III 2018]: <http://ec.europa.eu/archives/emu_history/documentation/chapter5/ 19701008en72realisationbystage.pdf $>$.

4 Report of the Study Group on the role of the public finance in European integration, Commission of the European Communities, Brussels, April 1977 [raport McDougalla], dostępny w internecie [dostęp: 1 III 2018]: <http://ec.europa.eu/archives/emu_history/ documentation/chapter8/19770401en73macdougallrepvol1.pdf $>$.

5 Report on economic and monetary union in the Community, Committee for the Study of Economic and Monetary Union, June 1989 [raport Delors'a], dostępny w internecie [dostęp: 25 II 2018]: <http://ec.europa.eu/economy_finance/publications/pages/ publication6161_en.pdf>. 
towanej na centralnym szczeblu strefy euro jednolitej polityce pieniężnej nie towarzyszy jednolita polityka budżetowa, gdyż kompetencje do jej określania pozostały w gestii państw członkowskich. W miarę bezproblemowo strefa euro funkcjonowała w takim kształcie przez kilka pierwszych lat, ale słabości jej konstrukcji wyraźnie pokazał niedawny globalny kryzys finansowy, który z problemu dotykającego przede wszystkim banki stał się kryzysem zadłużenia publicznego.

\section{Działania antykryzysowe w strefie euro}

Praktyka pokazała, że rynki nie miały takiej siły sprawczej, jak początkowo zakładano, a wyrazem tego było zbliżenie oprocentowania obligacji skarbowych poszczególnych krajów członkowskich widoczne przed kryzysem. Papiery emitowane przez państwa słabsze ekonomicznie i najbardziej zadłużone traktowane były przez rynki jako mało ryzykowne ${ }^{6}$. Okazało się jednak, że to właśnie te kraje: Grecja, Portugalia, Irlandia, Hiszpania i Cypr, zostały najbardziej dotknięte kryzysem finansowym, a następnie kryzysem zadłużenia publicznego i bez zewnętrznej pomocy finansowej nie byłyby sobie $\mathrm{w}$ stanie $\mathrm{z}$ nim poradzić. Na początku skierowana do nich pomoc pochodziła z tymczasowego mechanizmu pomocowego (European Financial Stabilisation Facility - EFSF) utworzonego w 2010 r. przez państwa strefy euro. Na mocy traktatu z lutego 2012 r., zawartego przez rządy tych państw poza ramami prawnymi UE, EFSF został przekształcony w trwałe rozwiązanie - Europejski Mechanizm Stabilności (European Stability Mechanism ESM). Ustanowiony jako międzynarodowa instytucja finansowa zaczął on funkcjonować w październiku 2012 r. Przez następne lata jego działalność pożyczkowa, realizowana przy udziale Międzynarodowego Funduszu Walutowego, była kluczowym źródłem wsparcia finansowego dla najmocniej dotkniętych kryzysem państw strefy euro.

Gdy okazało się, że powyższe kroki, podejmowane wspólnie przez rządy krajów strefy euro, nie są w stanie zahamować kryzysu, EBC zdecydował się na podjęcie szeroko zakrojonych działań interwencyjnych, zgodnie z deklaracją, którą w lipcu 2012 r. złożył jego prezes Mario Draghi, stwierdzając, że w ramach swego mandatu bank zrobi, co trzeba (,whatever it takes"),

6 P. Genschel, M. Jachtenfuchs, From market integration to core state powers. The Eurozone crisis, the refugee crisis and integration theory, ,Journal of Common Market Studies" 2018, vol. 56, No. 1, s. 178-196. 
by zachować euro ${ }^{7}$. Zapewnienie to miało ogromne znaczenie dla stłumienia paniki na rynkach finansowych, gdzie coraz powszechniejsza była obawa, że strefa euro może się rozpaść. Jednym $\mathrm{z}$ istotnych działań antykryzysowych podjętych przez EBC w ramach niestandardowych środków polityki pieniężnej określanych jako poluzowanie ilościowe (Quantitative Easing) było uruchomienie w 2012 r. programu OMT (Outright Monetary Transactions), czyli nielimitowanego skupu na rynku wtórnym obligacji skarbowych emitowanych przez te z najbardziej dotkniętych kryzysem krajów członkowskich, które zobowiązały się do przeprowadzenia reform. W 2015 r. EBC znacznie rozszerzył swoją aktywność, wprowadzając programy skupowania od banków komercyjnych aktywów finansowych emitowanych przez podmioty publiczne i prywatne ${ }^{8}$. Uruchomienie OMT oraz innych programów interwencyjnych pozwoliło na zwiększenie zaufania inwestorów do krajów przeżywających największe trudności finansowe i w efekcie złagodziło presję na zwiększenie oprocentowania ich papierów skarbowych.

Oznaczało to też, że EBC stał się faktycznie pożyczkodawcą ostatniej instancji dla banków działających w strefie euro, a przez nie pośrednio także dla rządów tych państw. Profesor Hans-Werner Sinn z Uniwersytetu Ludwika i Maksymiliana w Monachium wskazuje, że tylko w latach 2015-2017 EBC skupił $\mathrm{w}$ ramach działań ratunkowych papiery skarbowe na kwotę 1,8 bln euro. W rzeczywistości cały program poluzowania ilościowego był zdaniem Sinna ogromną operacją restrukturyzacji zadłużenia publicznego, a jej głównymi beneficjentami stały się południowe kraje strefy euro, które sprzedały dzięki temu dużą część obligacji rządowych zagranicznym inwestorom. Koszty tej operacji spadły w praktyce na Niemcy, Austrię i kilka innych krajów strefy euro i to ich krajowe banki centralne, stanowiące wraz z EBC część Eurosystemu, mają teraz roszczenia wobec banków centralnych z krajów południa strefy euro. Jeśli nie uda się ich zrealizować, to w praktyce będzie to równoznaczne z ogromnym transferem fiskalnym z północy na południe strefy ${ }^{9}$. Podobną opinię wyraził Wolfgang Münchau, stwierdzając, że realizowany

7 Key excerpts: Mario Draghi says ECB 'Ready to do whatever it takes', „The Wall Street Journal" [online], 26 VII 2012 [dostęp: 21 VII 2019], dostępny w internecie: <https:// blogs.wsj.com/economics/2012/07/26/key-excerpts-mario-draghi-says-ecb-ready-to-dowhatever-it-takes/>.

8 Asset purchase programmes, „European Central Bank” [online, dostęp: 19 II 2018], dostępny w internecie: $<$ https://www.ecb.europa.eu/mopo/implement/omt/html/index.en.html $>$.

9 H.W. Sinn, How to start paying off southern Europe's debts, ,The Guardian” [online], 29 I 2018 [dostęp: 12 II 2018], dostępny w internecie: <https:/www.theguardian.com/ business/2018/jan/29/how-to-start-paying-off-southern-europes-debts $>$. 
przez EBC program skupu aktywów stanowił pośrednie uwspólnotowienie długów krajów strefy euro. Nie było to oficjalnym celem tego programu, ale stało się jego efektem ubocznym ${ }^{10}$.

Generalnie działania EBC podjęte w sytuacji poważnego zagrożenia dla istnienia strefy euro mocno przyczyniły się do powstrzymania kryzysu zadłużenia publicznego i miały istotny wpływ na uratowanie tej strefy w sytuacji braku odrębnego budżetu i scentralizowanej polityki budżetowej. System bankowy strefy euro został wzmocniony dzięki podjęciu do realizacji projektu unii bankowej, w ramach której stworzono wspólny nadzór bankowy i przyjęto zasady postępowania wobec upadających banków.

\section{Unia fiskalna i odrębny budżet dla strefy euro}

Główne zastrzeżenia wobec idei unii fiskalnej w strefie euro dotyczą tego, że jej realizacja może prowadzić do trwałych jednokierunkowych transferów między państwami członkowskimi i w rezultacie stać się instrumentem redystrybucji dochodów na rzecz państw słabszych ekonomicznie. Mogłoby to zniechęcić je do reform i przyczynić się do utrwalenia różnic w poziomie rozwoju. Postuluje się więc, by w ewentualnej unii fiskalnej system transferów finansowych powiązać $\mathrm{z}$ mechanizmami zapewniającymi realizację reform strukturalnych i ochronę przed prowadzeniem przez państwa zbyt luźnej polityki budżetowej ${ }^{11}$.

Na przykładzie Stanów Zjednoczonych można stwierdzić, że transfery fiskalne są niezbędnym warunkiem harmonijnego funkcjonowania unii walutowej. Uczestniczące w niej regiony mają dzięki nim większe możliwości reagowania zarówno na wstrząsy symetryczne, czyli dotykające wszystkie te regiony, jak i asymetryczne, dotykające tylko niektóre z nich. Transfery fiskalne netto ze stanów bogatszych do biedniejszych (stanowiące różnicę między tym, co dany stan otrzymuje z budżetu federalnego, a tym, co do niego wpłaca) mają istotny efekt stabilizacyjny, a także redystrybucyjny. W przypadku pogorszenia sytuacji gospodarczej $\mathrm{w}$ danym stanie wpłaca on do federalnego budżetu mniej z tytułu podatków, a jednocześnie automatycznie rosną różne federalne wydatki na jego rzecz, np. na zasiłki dla bezrobotnych. W latach 2000-2010 aż 27 z 50 stanów było beneficjentami netto środków

10 W. Münchau, Macron's fiscal union points the way for Euro-Bonds, „Financial Times”, 22 V 2017.

11 G. Thirion, European Fiscal Union: Economic rationale and design challenges, CEPS, [Brussels] 2017 (Working Document, 2017/01). 
z budżetu federalnego, a w przypadku 13 łączna wartość otrzymanych transferów netto była wyższa niż osiągnięty przez nie poziom PKB w 2010 r. (w stanach Missisipi i Nowy Meksyk niemal dwukrotnie wyższa od tego pozio$\mathrm{mu})^{12}$. Szacuje się, że gdyby strefę euro charakteryzował federalizm fiskalny o podobnej skali co w Stanach Zjednoczonych, to transfery netto w latach 2000-2010 musiałyby być kilkukrotnie, a czasami nawet kilkunastokrotnie wyższe od zrealizowanych w praktyce. Te rzeczywiste transfery netto to różnica między wpłatami danego kraju do budżetu ogólnego Unii Europejskiej oraz otrzymanymi z niego wypłatami. U największych beneficjentów netto transfery od innych krajów strefy euro otrzymane w latach 2000-2010 poprzez budżet ogólny UE wyniosły: 47,2 mld euro w przypadku Grecji (21,26 proc. jej PKB z 2010 r. i jedynie 0,51 proc. PKB strefy euro) i 71,2 mld euro w przypadku Hiszpanii (odpowiednio 6,79 i 0,78 proc. PKB). Największym płatnikiem netto były w tym okresie Niemcy - łącznie 79,1 mld euro (3,17 proc. PKB tego kraju i zaledwie 0,86 proc. PKB całej strefy euro w 2010 r.). Gdyby $\mathrm{w}$ strefie euro funkcjonował w badanym okresie federalizm fiskalny, to wpłaty Niemiec do budżetu wyniosłyby aż 320,8 mld euro netto (12,85 proc. ich PKB i 3,49 proc. PKB strefy euro w 2010 r.). Grecja otrzymałaby wówczas aż 200,8 mld euro netto (90,39 proc. jej PKB i 2,19 proc. PKB strefy euro w 2010 r.), a Hiszpania - 485,7 mld euro (odpowiednio 46,30 i 5,29 proc. PKB $)^{13}$. Szacunki te wskazują, że słabsze ekonomicznie kraje strefy euro mogłyby uzyskać duże transfery, co dla państw będących dotychczas płatnikami netto oznaczałoby znaczny wzrost ciężaru ich sfinansowania.

Istotna dla unii fiskalnej kwestia solidarności fiskalnej znalazła pewne ograniczone odzwierciedlenie w opublikowanych w czerwcu 2012 r. propozycjach pogłębienia integracji w ramach unii gospodarczej i walutowej przygotowanych przez przewodniczącego Rady Europejskiej we współpracy z przewodniczącymi Komisji i Eurogrupy oraz prezesem $\mathrm{EBC}^{14}$. Przedstawiono w nich wizję tej unii obejmującą m.in. zintegrowane ramy finansowe, mające zapewniać stabilność finansową (szczególnie w strefie euro) i minimalizować koszty upadku banków, głównie dzięki przeniesieniu odpowiedzialności

12 J.K. Dreyer, P.A. Schmid, Fiscal federalism in monetary unions. Hypothetical fiscal transfers within the Euro-zone, „International Review of Applied Economics” 2015, vol. 29 , issue 4.

13 Tamże.

$14 W$ kierunku faktycznej unii gospodarczej $i$ walutowej. Sprawozdanie przewodniczacego Rady Europejskiej Hermana Van Rompuya, Bruksela, 26 VI 2012, dostępne w internecie [dostęp: 17 X 2019]: <https://www.consilium.europa.eu/uedocs/cms_data/docs/pressdata/PL/ec/131295.pdf $>$. 
za nadzór na szczebel europejski oraz zapewnieniu wspólnych mechanizmów restrukturyzacji i uporządkowanej likwidacji banków oraz gwarantowania depozytów bankowych. Drugim ważnym elementem UGW w nowym kształcie miałyby być zintegrowane ramy budżetowe, obejmujące głównie koordynację polityki budżetowej państw członkowskich, a także pewne działania na rzecz wspólnej emisji długu i różne formy solidarności fiskalnej. Rozwinięcia powyższych propozycji dokonano w kolejnym sprawozdaniu, opublikowanym 5 grudnia 2012 r. Odnosząc się do solidarności, podkreślono, że elementy fiskalnego podziału ryzyka związane z amortyzacją wstrząsów w poszczególnych krajach powinny być określone w taki sposób, by nie prowadziły do jednokierunkowych i trwałych transferów między państwami i nie były postrzegane jako narzędzie wyrównywania dochodów ${ }^{15}$. Mimo złagodzenia wydźwięku pierwotnych propozycji idea podjęcia jakichś znaczących działań w kierunku integracji fiskalnej nie znalazła wyraźnego poparcia Rady Europejskiej ani na posiedzeniu w grudniu 2012 r., ani na kolejnych. Zdecydowanie opowiedziała się ona za tworzeniem wskazanych wyżej zintegrowanych ram finansowych ${ }^{16}$.

Uwzględniając doświadczenia strefy euro związane z kryzysem finansowym z lat 2007-2009 oraz będącym jego następstwem kryzysem zadłużenia publicznego, Komisja Europejska opublikowała w czerwcu 2015 r. propozycje niezbędnych działań, które należy podjąć, by dokończyć budowę unii gospodarczej i walutowej (tzw. raport pięciu przewodniczących). Poza sfinalizowaniem tworzenia unii bankowej wskazano tu na konieczność osiągnięcia postępu na drodze do unii fiskalnej, mającej zapewnić zarówno długookresową stabilność budżetową, jak i fiskalny mechanizm stabilizacyjny w strefie euro ${ }^{17}$.

Dyskusja nad ideą unii fiskalnej znacznie się ożywiła, gdy w maju 2017 r. Emmanuel Macron zgłosił propozycję ustanowienia odrębnego budżetu dla strefy euro. Jego głównymi funkcjami miałyby być inwestowanie w rozwój, udzielanie pilnego wsparcia finansowego oraz reagowanie

15 H. Van Rompuy, W kierunku faktycznej unii gospodarczej $i$ walutowej, 5 XII 2012, dostępny w internecie [dostęp: 17 X 2019]: <https://www.consilium.europa.eu/media/23809/134201.pdf $>$.

16 Konkluzje - 13-14 XII 2012 r., EUCO 205/12, Rada Europejska, Bruksela, 14 XII 2012, dostępne w internecie [dostęp: 6 IX 2017]: <https://www.consilium.europa.eu/uedocs/ cms_data/docs/pressdata/PL/ec/134361.pdf $>$.

17 J.-C. Juncker, Dokończenie budowy europejskiej Unii Gospodarczej $i$ Walutowej, Komisja Europejska, 22 VI 2015, s. 5, dostępny w internecie [dostęp: 6 IX 2017]: <https:// ec.europa.eu/commission/sites/beta-political/files/5-presidents-report_pl.pdf $>$. 
na kryzysy ekonomiczne ${ }^{18}$. Uzasadniając potrzebę radykalnych zmian w strefie euro, prezydent Francji wielokrotnie wskazywał, że dotychczasowe zasady funkcjonowania strefy euro przyczyniły się do pogłębienia różnic między jej krajami członkowskimi, w wyniku czego państwa poważnie zadłużone zadłużyły się jeszcze bardziej, a te, które były wysoko konkurencyjne, jak Niemcy, stały się jeszcze bardziej konkurencyjne. Ze środków z odrębnego budżetu miałyby korzystać przede wszystkim kraje członkowskie mające problemy gospodarcze, a on sam miałby być elementem silnego mechanizmu solidarnościowego ${ }^{19}$.

Propozycje Macrona spotkały się z różnymi reakcjami. Profesor Dani Rodrik z Uniwersytetu Harvarda uznał ewentualne stworzenie takiego budżetu za ambitny krok w kierunku unii fiskalnej strefy euro, w ramach której możliwe byłyby stałe transfery fiskalne od państw silniejszych do słabszych, mających problemy z funkcjonowaniem w obszarze o jednolitej polityce pieniężnej. Unia fiskalna, wsparta głębszą integracją polityczną, miałaby według niego sens, gdyż stanowiłaby spójną ścieżkę odejścia strefy euro od obecnego statusu ziemi niczyjej ${ }^{20}$. Christoph M. Schmidt z Leibniz Institute for Economic Research wskazuje z kolei, że ustanowienie w strefie euro odrębnego budżetu stanowić będzie zarzewie przyszłych konfliktów między krajami członkowskimi. Krajowi decydenci, broniąc interesów swych państw, nie będą bowiem w stanie zapobiec przekształceniu się tego rodzaju porozumienia $\mathrm{w}$ stały system asymetrycznych transferów ${ }^{21}$. Także Guntram B. Wolff z brukselskiego Bruegela podkreśla, że z politycznego punktu widzenia $w$ ramach unii walutowej nie da się utrzymać na dłuższą metę dużych jednostronnych transferów, a to ze względu na sprzeciw krajów, które miałyby je finansować. Poza tym służyłoby to utrwaleniu słabości gospodarek będących przyczyną problemów finansowych słabszych ekonomicznie krajów strefy euro. Bardziej niż tworzenie dodatkowego

18 Une Europe qui protège les Européens, „En Marche!” [online, dostęp: 6 IX 2017], dostępny w internecie: <https://en-marche.fr/emmanuel-macron/le-programme/europe>.

19 W. Horobin, Macron pushes Germany to commit more to Eurozone, „Wall Street Journal” [online], 13 VII 2017 [dostęp: 9 I 2018], dostępny w internecie: <https://www.wsj.com/ articles/macron-pushes-germany-to-commit-more-to-eurozone-1499946041>.

20 D. Rodrik, Can Macron pull it off?, „Project Sindicate” [online], 9 V 2017 [dostęp: 27 VIII 2018], dostępny $\mathrm{w}$ internecie: <https://www.project-syndicate.org/commentary/macron-germany-eurozone-fiscal-union-by-dani-rodrik-2017-05?barrier=accesspaylog $>$.

21 Ch.M. Schmidt, How to renew the European project, „Project Sindicate” [online], 1 IX 2017 [dostęp: 27 X 2017], dostępny w internecie: <https://www.project-syndicate.org/ commentary/european-integration-france-germany-by-christoph-m--schmidt-2017-09? barrier=accesspaylog $>$. 
budżetu dla strefy euro potrzebna jest jego zdaniem odpowiednia polityka zmian strukturalnych ${ }^{22}$.

Jak zauważa Hubert Gabrisch z Wiesbaden Institute for Law and Economics, ustanowienie odrębnego budżetu dla strefy euro musiałoby się wiązać z powołaniem do życia odpowiedniej władzy, która miałaby nim zarządzać. To z kolei wymagałoby zmian traktatowych, gdyż jeśli budżet ten dysponowałby trwałymi dochodami podatkowymi i realizował wydatki, to spełniałby nie tylko funkcję stabilizacyjną, ale także alokacyjną i redystrybucyjną. Główną przeszkodą w jego realizacji jest wrażliwa politycznie kwestia suwerenności krajów członkowskich ${ }^{23}$. Do zarządzania takim budżetem trzeba by było bowiem powołać instytucję, której kraje musiałyby przekazać część swych uprawnień.

\section{Unia bankowa - etapem do unii fiskalnej?}

Unia fiskalna - ze wspólnym budżetem finansowanym z podatków i zarządzanym przez niezależną władzę centralną, mającą uprawnienia do emitowania długu, za który odpowiadałyby wszystkie państwa strefy euro - postrzegana jest na ogół jako mało realne rozwiązanie w dającej się przewidzieć przyszłości. Wynika to przede wszystkim z niechęci części krajów członkowskich (zwłaszcza Niemiec) do ponoszenia kosztów wynikających z nadmiernego zadłużania się innych państw. W tej sytuacji pragmatycznym rozwiązaniem, możliwym do zrealizowania na obecnym etapie integracji politycznej w ramach UE, a w szczególności w strefie euro, okazała się unia bankowa. Jej podstawą jest założenie, że jeśli koszty upadku banków byłyby ponoszone przez ich właścicieli i wierzycieli, to można ograniczyć destabilizujący wpływ, jaki na stan finansów publicznych mają wydatki państwa na pomoc dla sektora finansowego, w tym upadających banków. W ten sposób zminimalizowana zostałaby potrzeba udzielania danemu krajowi wsparcia finansowego przez inne kraje członkowskie, a więc potrzeba solidarności fiskalnej. Pomoc udzielona sektorowi finansowemu przez rządy w latach 2008-2014 spowodowała wzrost długu publicznego w strefie euro o 4,8 proc. PKB, co stanowiło około jedną piątą jego całkowitego przyrostu w tym okresie, wynoszącego 27 proc.

22 G.B. Wolff, Eurozone or EU budget? Confronting a complex political question, „Bruegel” [online], 29 VI 2017 [dostęp: 27 VIII 2017], dostępny w internecie: <https://bruegel. org/2017/06/eurozone-or-eu-budget-confronting-a-complex-political-question/>.

23 H. Gabrisch, A fire department for the Euro area. Reflections on a fiscal risk-sharing capacity, Munich Personal RePEc Archive, 18 I 2018 (MPRA Paper, 83965). 
PKB (z 65 do 92 proc. PKB). W niektórych krajach przyrost zadłużenia publicznego wynikający tej pomocy był szczególnie duży: w Irlandii wyniósł aż 31,1 proc. PKB, a w Grecji i na Cyprze - ok. 20 proc. $^{24}$

Polityczna decyzja o stopniowym budowaniu unii bankowej podjęta została przez Radę Europejską w grudniu 2012 r. Zgodnie z przyjętymi następnie regulacjami ${ }^{25}$ unia ta opiera się na trzech filarach, przy czym dwa zostały już stworzone. Pierwszym jest funkcjonujący od listopada 2014 r. jednolity mechanizm nadzoru (Single Supervisory Mechanism), będący narzędziem bezpośredniej lub pośredniej kontroli EBC nad bankami w strefie euro. Przeniesienie do EBC władzy nadzorczej nad bankami uznane zostało za konieczne z uwagi na słabości dotychczasowego systemu koordynacji między krajowymi władzami nadzorczymi. Drugi filar to działający od stycznia 2016 r. mechanizm restrukturyzacji i uporządkowanej likwidacji banków (Single Resolution Mechanism - SRM), który ma zapewnić skuteczną likwidację upadających banków przy jednoczesnym zredukowaniu do minimum wynikających z tego tytułu obciążeń dla finansów publicznych. Przyjęto, że w ramach SRM będzie można przeznaczać środki na ratowanie upadających banków dopiero po tym, jak odpowiednie ciężary poniosą akcjonariusze (poprzez częściowe umorzenie kapitału), wierzyciele i deponenci oraz po odpowiednim wykorzystaniu środków z tworzonego ze składek banków Jednolitego Funduszu Restrukturyzacji i Uporządkowanej Likwidacji (Single Resolution Fund - SRF). W szczególnie pilnych sytuacjach fundusz ten otrzymywałby zwrotne wsparcie finansowe z przyszłego Europejskiego Funduszu Walutowego, jeśli taki zostanie utworzony. Trzecim filarem powinien być jednolity dla całej strefy euro Europejski System Gwarantowania Depozytów (European Deposit Insurance Scheme - EDIS), który zgodnie z propozycją Komisji z 2015 r. miałby funkcjonować w pełni od 2024 r. ${ }^{26}$ System ten miałby zwiększyć zaufanie do sektora bankowego w strefie euro, a w efekcie jego stabilność, a zbudowany byłby w oparciu o krajowe systemy gwarantowania depozytów. Na szczeblu strefy euro powstałby fundusz gwarancyj-

24 The fiscal impact of financial sector support during the crisis, „ECB Economic Bulletin” 2015, issue 6, s. 79.

25 Szerzej zob. Communication to the European Parliament, the Council, the European Central Bank, the European Economic and Social Committee and Committee of the Regions on completing the Banking Union, COM(2017) 592 final, European Commission, Brussels, 11 X 2017.

26 Wniosek Rozporzadzenie Parlamentu Europejskiego i Rady zmieniajace rozporzadzenie (UE) $n r$ 806/2014 w celu ustanowienia europejskiego systemu gwarantowania depozytów, $\operatorname{COM(2015)~} 586$ final, Komisja Europejska, Strasburg, 24 XI 2015. 
ny (European Deposit Guarantee Fund), do którego składki wnosiłyby banki krajów członkowskich.

Potrzeba ustanowienia EDIS wynika ze słabości krajowych systemów gwarantowania depozytów. Mimo że na mocy dyrektywy Parlamentu Europejskiego i Rady z 16 kwietnia 2014 r. ${ }^{27}$ stworzone zostały regulacje zapewniające jednolity w całej UE poziom ochrony depozytów, żaden $\mathrm{z}$ nich nie poradzi sobie samodzielnie $\mathrm{z}$ wypłatą gwarantowanych depozytów w przypadku upadłości dużego banku. Ponieważ znaczna część krajowych systemów gwarantowania depozytów jest niedofinansowana, to nie poradziłyby sobie one z niewypłacalnością banku systemowo ważnego (global systemically important bank). Tymczasem właścicielami prawie dwóch trzecich aktywów banków działających na rynku bankowym UE są właśnie duże banki międzynarodowe. Ze względu na ich znaczącą działalność transgraniczną koszty zaangażowania państwa w ich ratowanie mogą być dramatycznie wysokie z punktu widzenia finansów publicznych, co było wyraźnie widać w czasie niedawnego kryzysu. Wynikła stąd potrzeba stworzenia skutecznych instrumentów prawnych, które umożliwiałyby restrukturyzację i likwidację banków bez konieczności angażowania środków publicznych, dzięki przeniesieniu zarządzania kryzysowego na szczebel UE, oraz stworzenia instytucji zdolnych do szybkiej interwencji. Za istotne uznano też jednak nadanie systemowi gwarantowania depozytów nowej roli w sieci bezpieczeństwa finansowego. Ustanowienie EDIS byłoby więc logicznym dopełnieniem przeniesienia odpowiedzialności za nadzór bankowy, restrukturyzację i uporządkowaną likwidację na poziom unii bankowej. Brak wspólnego systemu gwarantowania depozytów w unii bankowej osłabia ochronę deponentów, gdyż kryzysy o znaczeniu systemowym mogą przerosnąć możliwości finansowe krajowych systemów gwarancyjnych ${ }^{28}$.

Idea ustanowienia takiego systemu spotykała się dotychczas ze zdecydowanym sprzeciwem Niemiec, które obawiają się, że to głównie na ich banki spadną koszty zbyt ryzykownej działalności banków z innych krajów strefy euro ${ }^{29}$. David Howarth i Lucia Quaglia z Uniwersytetu Luksemburskiego

27 Dyrektywa Parlamentu Europejskiego i Rady 2014/49/UE z dnia 16 kwietnia 2014 r. w sprawie systemów gwarancji depozytów, Dz. Urz. UE L 173, 12 VI 2014.

28 A. Jurkowska-Zeidler, Europejski System Gwarantowania Depozytów: trzeci brakujacy filar do dokończenia Unii Bankowej, „Annales Universitatis Mariae Curie-Skłodowska. Sectio H" 2016, vol. 50, No. 4.

29 J. Brunsden, Germany stands firm against EU bank deposit guarantee plan, „Financial Times" [online], 11 X 2017 [dostęp: 3 III 2018], dostępny w internecie: $<$ https://www.ft.com/ content/58c9a172-ae7d-11e7-beba-5521c713abf4>. 
podkreślają, że brak akceptacji władz niemieckich dla EDIS wynika właśnie z obawy, że dla banków z państw mających słaby system bankowy będzie to silna pokusa do nadużywania wspólnych funduszy. Dobrze finansowany niemiecki system gwarancji depozytów może więc zostać wykorzystany, aby zrekompensować niedofinansowane (i w dużej mierze finansowane ex post) systemy gwarancji depozytów w innych państwach członkowskich. W ten sposób autorzy ci pokazują, że trudności występujące przy budowie EDIS wynikają ze słabości dotychczasowej harmonizacji krajowych systemów gwarancji depozytów ${ }^{30}$. Jak podkreśla Krzysztof Waliszewski, w przypadku upadłości banków z kraju, gdzie system bankowy boryka się z problemami wynikającymi z niedostatecznego nadzoru w przeszłości i słabego systemu gwarancyjnego, konieczność zrealizowania gwarancji przez fundusz paneuropejski będzie się wiązała z redystrybucją środków finansowych od dobrze nadzorowanych systemów i dobrze zarządzanych banków ${ }^{31}$.

Poszukując rozwiązania, w którym ryzyko redystrybucji na rzecz słabszych systemów bankowych mogłoby być znacznie zmniejszone, Esa Jokivuolle i George G. Pennacch stwierdzili, że taki system dałoby się zaprojektować. Jego kluczowe cechy konstrukcyjne obejmowałyby m.in. wymogi posiadania przez banki odpowiednio wysokiego kapitału własnego oraz ponoszenia przez nie na rzecz Europejskiego Mechanizmu Stabilności systematycznej opłaty za ryzyko ${ }^{32}$. Wydaje się jednak mało prawdopodobne, by to pragmatyczne rozwiązanie zostało zrealizowane w najbliższej przyszłości. Dość powszechny jest pogląd, że Niemcy mogą blokować EDIS, dopóki banki nie wyeliminują bilansów złych kredytów, w tym tych, które są rezultatem kryzysu finansowego. Ryzyko, że będą one potrzebować pomocy, jest po prostu zbyt duże, by Niemcy mogły wziąć na siebie ciężar ochrony ich deponentów w ramach wspólnego systemu. Podobne podejście prezentuje kilka innych państw strefy euro. Warunkują one ustanowienie EDIS osiągnięciem wystarczających postępów w zmniejszaniu ryzyka związanego z działalnością banków, w szczególności w południowych państwach strefy euro. Miałoby temu służyć m.in. przyjęcie przez banki limitów nabywania skarbowych papierów

30 D. Howarth, L. Quaglia, The difficult construction of a European Deposit Insurance Scheme: a step too far in Banking Union?, „Journal of Economic Policy Reform” 2018, No. 21, issue 3, s. 190-209.

31 K. Waliszewski, Europejski System Gwarantowania Depozytów jako trzeci element Unii Bankowej, „Bezpieczny Bank” 2016, nr 1 (62).

32 E. Jokivuolle, G. G. Pennacch, How to design the European Deposit Insurance Scheme, „Vox" [online], 31 V 2019 [dostęp: 16 X 2019], dostępny w internecie: <https://voxeu. org/article/how-design-european-deposit-insurance-scheme $>$. 
dłużnych, czemu szczególnie ostro sprzeciwiały się dotychczas Włochy, uznające, że może się to przyczynić do znacznego wzrostu kosztów finansowania długu publicznego ${ }^{33}$.

Różne stanowiska państw członkowskich odnośnie do EDIS stanowią odzwierciedlenie ogólnej struktury i kondycji krajowych systemów bankowych, a także istniejących uprzednio krajowych systemów gwarancji depozytów. Pomimo ponad sześćdziesięciu lat integracji finansowej w UE i znacznych postępów w budowie jednolitego rynku finansowego krajowe systemy bankowe dalej pozostają silnie zróżnicowane, co utrudnia postęp na drodze do ustanowienia EDIS. Poza tym, jak zauważa Małgorzata Zaleska, od początku było wiadomo, że podstawowym problemem w stworzeniu EDIS będzie zgromadzenie wystarczających środków finansowych na jego funkcjonowanie. Nie należy sądzić, że zostanie on rozwiązany w najbliższym czasie, gdyż w miarę wychodzenia z kryzysu skłonność państw do wprowadzania reform będzie spadała ${ }^{34}$.

Dokończenie budowy unii bankowej poprzez stworzenie jej trzeciego filaru postrzega się często jako pilne zadanie stojące przed strefą euro w obliczu ciągłej wrażliwości krajowych systemów bankowych na różne zagrożenia. EDIS mógłby być kompromisem między potrzebą zmniejszenia ryzyka ponoszonego przez banki oraz potrzebą zapewnienia większego podziału ryzyka i fiskalnego mechanizmu ochronnego (fiscal backstop) ${ }^{35}$. W ten sposób unia bankowa stałaby się ograniczoną wersją unii fiskalnej, która funkcjonowałaby automatycznie, bez względu na decyzje polityczne. Ponieważ bardziej zaawansowane formy unii fiskalnej są mało prawdopodobne w krótkiej i średniej perspektywie, to pojawiają się oczekiwania, że pełna unia bankowa przynajmniej na pewien czas zakończyłaby debatę na temat integracji w tej sferze ${ }^{36}$. Istotnym uzupełnieniem unii bankowej zmniejszającym ryzyko ponoszone przez banki byłoby ograniczenie im możliwości nabywania skarbowych papierów dłużnych,

33 R. Berschens, J. Hildebrand, Nein, danke. Austria's compromise on European deposit insurance irritates Berlin, „Handelsblatt” [online], 13 IX 2018 [dostęp: 13 X 2019], dostępny w internecie: <https://www.handelsblatt.com/today/finance/nein-danke-austrias-compromise-on-european-deposit-insurance-irritates-berlin/23583320.html?ticket= ST-33407237-oPYtyuGbaEboedrbkrKd-ap2>.

34 M. Zaleska, Zintegrowane ramy finansowe - koncepcja $i$ wyzwania, [w:] Europejska Unia Bankowa, red. M. Zaleska, Difin, Warszawa 2015, s. 31.

35 S. Micossi, A blueprint for completing the Banking Union, CEPS, [Brussels] 2017 (Policy Insights, 2017/42).

36 M.M. Cózar, The only feasible fiscal union for the euro area, „European View”, $17 \mathrm{~V}$ 2017, s. 23-32. 
co pozwoliłoby zminimalizować ryzyko prowadzenia przez kraje członkowskie zbyt luźnej polityki budżetowej. W razie wpadnięcia w kryzys zadłużenia musiałyby one zrestrukturyzować swoje długi, zamiast otrzymywać pomoc finansową od innych państw członkowskich ${ }^{37}$.

Są też jednak głosy, że nawet pełna unia bankowa nie zapewni trwałości strefy euro. W styczniu $2018 \mathrm{r}$. minister finansów Grecji Euclid Tsakalotos stwierdził, że dokończenie jej budowy byłoby ważnym filarem reformy strefy euro, przyczyniającym się do zmniejszenia ryzyka odpływu depozytów z banków działających w krajach, które znalazłyby się w kryzysie. O ile jednak unia bankowa może być dobrym rozwiązaniem w sytuacji upadku pojedynczego banku, to niekoniecznie musi być skuteczna, gdy zaistnieje systemowy kryzys bankowy. Wtedy bowiem państwa i tak nieuchronnie będą interweniować i ponosić koszty w celu zatrzymania procesu upadania banków. Jeśli więc obywatele strefy euro odrzucą ideę wspólnego ponoszenia ciężarów fiskalnych w sytuacjach kryzysowych, to unia walutowa nigdy nie będzie kompletna ${ }^{38}$.

Wychodząc z założenia, że strefa euro nie ma obecnie wystarczających mechanizmów, by przeciwstawić się następnemu kryzysowi finansowemu, grupa czternastu profesorów (głównie z Niemiec i Francji) przedstawiła w styczniu 2018 r. propozycję zreformowania jej, łączącą istotną dla unii fiskalnej ideę uwspólnotowienia ryzyka z dyscyplinującym oddziaływaniem rynku na finanse publiczne ${ }^{39}$. Ma ona stanowić pragmatyczne rozwiązanie w obliczu istnienia dwóch odrębnych wizji integracji, reprezentowanych głównie przez Francję i Niemcy. Po pierwsze, banki powinny prezentować ostrożniejsze podejście przy zakupie obligacji rządowych i nie traktować ich jako aktywów wolnych od ryzyka. Posiadane przez banki portfele takich obligacji powinny być tak zdywersyfikowane, by nie było w nich zbyt dużo papierów emitowanych przez jeden lub kilka rządów. Pozwoliłoby to zmniejszyć ryzyko wynikające z powiązania sektora finansowego z finansami publicznymi. Finalnym krokiem w ramach reformy byłoby ustanowienie w strefie euro wspólnego

37 B. Eichengreen, The euro's narrow path, „Project Syndicate” [online], 11 IX 2017 [dostęp: 11 II 2018], dostępny w internecie: <https://www.project-syndicate.org/commentary/euro-narrow-path-france-germany-cooperation-by-barry-eichengreen-2017-09? barrier=accesspaylog $>$.

38 E. Tsakalotos, Banking union is not enough to save the eurozone, „Financial Times” [online], 7 I 2018 [dostęp: 11 II 2018], dostępny w internecie: <https://www.ft.com/ content/0096a770-f225-11e7-bb7d-c3edfe974e9f>.

39 A. Bénassy-Quéré i in., Reconciling risk sharing with market discipline. A constructive approach to euro area reform, Centre for Economic Policy Research, styczen 2018 (CEPR Policy Insight, 91). 
systemu gwarantowania depozytów bankowych. Po drugie, zamiast koncentrować się jak dotychczas na deficycie budżetowym, rządy powinny realizować długoterminowy cel redukcji długu, dbając o to, by wydatki publiczne nie rosły szybciej niż PKB (w przypadku krajów najbardziej zadłużonych powinny rosnąć nawet wolniej niż PKB). Przestrzegania tej zasady kontrolowałaby niezależna od władz politycznych instytucja mogąca powstać w ramach Komisji Europejskiej lub poza nią. Ponadto kredyty ratunkowe z ESM lub funduszu będącego jego następcą nie powinny być przyznawane krajom, które nie osiągną poprawy sytuacji finansowej. W ich przypadku zadłużenie będzie musiało zostać zrestrukturyzowane, a koszty tego procesu poniosą wierzyciele. Zaproponowano także stworzenie w strefie euro finansowanego ze składek państw członkowskich funduszu, który udzielałby pomocy krajom notującym poważne zakłócenia gospodarcze. Wypłaty uruchamiano by w przypadku przekroczenia w nich określonego poziomu bezrobocia. By zapewnić, że system nie będzie powodował stałych transferów, kraje, w przypadku których prawdopodobieństwo korzystania ze środków funduszu byłoby największe, musiałyby też wpłacać do niego wyższe składki. Jak wskazują autorzy tych propozycji, można je wprowadzić w życie bez zmian traktatowych.

\section{Unia bankowa a unia rynków kapitałowych}

Projektem komplementarnym do unii bankowej i ściśle z nią powiązanym jest realizowana od kilku lat inicjatywa stworzenia w UE unii rynków kapitałowych (Capital Markets Union - CMU). Fakt, że nie została ona dotychczas zbudowana, świadczy, że mimo znacznych postępów założenia tworzonego od kilkudziesięciu lat jednolitego rynku finansowego Unii Europejskiej dalekie są od pełnej realizacji ${ }^{40}$.

Projekt CMU stanowi szeroko zakrojone ramy reform regulacyjnych, które mają na celu zwiększenie inwestycji, wzrostu i zatrudnienia poprzez pogłębienie integracji rynków finansowych państw członkowskich. Integracja ta ma zwiększyć możliwości finansowania przedsiębiorstw i inwestycji transgranicznych oraz przyciągnąć nowy kapitał spoza UE. Impulsem do podjęcia prac nad CMU stała się potrzeba znalezienia nowych bodźców rozwojowych po globalnym kryzysie finansowym, wielkiej recesji i kryzysie zadłużeniowym w strefie euro w latach 2008-2014.

40 Na temat tych założeń zob. np. L. Oręziak, Rynek finansowy Unii Europejskiej, Twigger, Warszawa 1999. 
Uwzględniając te cele, Komisja Europejska przedstawiła we wrześniu 2015 r. Plan działania na rzecz tworzenia unii rynków kapitałowych ${ }^{41}$. Jego wdrożenie miało wyeliminować bariery ograniczające przedsiębiorstwom dotarcie do inwestorów. Przedstawiony przez Komisję plan obejmował ponad dwadzieścia reform, które miały zostać opracowane i wdrożone w ciągu czterech lat, czyli do zakończenia ówczesnej kadencji w 2019 r. Przyjęto, że reformy dotyczące wielu obszarów polityki związanej z rynkami kapitałowymi w UE powinny się koncentrować na ułatwieniu wszystkim przedsiębiorstwom (w tym małym i średnim) dostępu do finansowania oraz stworzeniu większych możliwości inwestycyjnych dla inwestorów indywidualnych i instytucjonalnych. Oceniając wdrażanie założeń CMU, Komisja Europejska przedstawiła w marcu 2019 r. listę przyjętych regulacji, a także stan zaawansowania procesu legislacyjnego w odniesieniu do pozostałych zaproponowanych działań ${ }^{42}$. $\mathrm{Z}$ raportu tego wynika, że unijne regulacje przyjęte zostały jedynie w nielicznych kwestiach (m.in. sekurytyzacji, prospektu emisyjnego, europejskich funduszy wysokiego ryzyka), a w odniesieniu do pozostałych regulacje nie zostały jeszcze wydane, choć co do większości udało się już osiągnąć porozumienie w ramach Parlamentu Europejskiego i Rady. Może to oznaczać, że regulacje te zostaną uzgodnione w nieodległej przyszłości.

Generalnie projekt budowy unii rynków kapitałowych został podjęty jako niezbędne uzupełnienie unii bankowej, a więc także w celu wzmocnienia unii gospodarczej i walutowej oraz międzynarodowej roli euro. Obranie takiego kierunku działań wynika z przekonania, że głębsza integracja rynków kapitałowych wraz $z$ bardziej zintegrowanymi systemami bankowymi powinna pomóc w utrzymaniu transgranicznych przepływów kapitału i podtrzymaniu inwestycji w państwach członkowskich, co może być szczególnie istotne w razie wystąpienia dużych wstrząsów makroekonomicznych o charakterze asymetrycznym. Unia rynków kapitałowych powinna zapewnić mechanizmy podziału ryzyka mogące odgrywać szczególnie ważną rolę w łagodzeniu szoków specyficznych dla poszczególnych państw członkowskich i przyczyniające się do zmniejszenia ryzyka w sektorze finansowym. Warto zwrócić uwagę, że unia rynków kapitałowych niesie z sobą do rozwiązania liczne problemy, które wskazuje Alfred Janc.

41 Plan działania na rzecz tworzenia unii rynków kapitałowych, $\operatorname{COM(2015)~} 468$ final, Komisja Europejska, Bruksela, 30 IX 2015.

42 Capital Markets Union: progress on building a single market for capital for a strong Economic and Monetary Union, $\operatorname{COM(2019)~} 136$ final, European Commission, Brussels, 15 III 2019, dostępny w internecie [dostęp: 12 X 2019]: <https://ec.europa.eu/finance/ docs/policy/190315-cmu-communication_en.pdf $>$. 
Znajduje się wśród nich kwestia gotowości przywiązanych do lokalnego finansowania mikro-, małych i średnich przedsiębiorstw (MMŚP), by wychodzić po kapitał na rynki zagraniczne, gdzie wymogi dopuszczenia oraz obowiązki informacyjne są bardziej rygorystyczne niż na ich rynkach lokalnych, a w rezultacie trzeba ponosić wyższe koszty. Jest też pytanie, w jaki sposób ograniczać ryzyko inwestycyjne potencjalnych inwestorów, gdy nie mogą mieć zastosowania ratingi nadawane przez organizacje międzynarodowe, a na poziomie europejskim nie istnieją biura informacji gospodarczej gromadzące dane o wiarygodności finansowej podmiotów z sektora MMŚP ${ }^{43}$. Są to ważne czynniki ograniczające możliwości łagodzenia problemów z finansowaniem firm na rynku krajowym poprzez korzystanie z kapitału dostępnego na rynkach innych państw UE.

$Z$ drugiej strony unia bankowa jest niezbędnym uzupełnieniem unii rynków kapitałowych, gdyż zakładana w niej ściślejsza integracja krajowych rynków kapitałowych i stopniowa eliminacja istniejących między nimi barier może stwarzać nowe zagrożenia dla stabilności finansowej państw członkowskich. $Z$ tego względu ważne jest, by unijne i krajowe organy nadzorujące rynek kapitałowy działały spójnie i dysponowały odpowiednimi instrumentami pozwalającymi na monitorowanie i zarządzanie ryzykiem systemowym. Konwergencja praktyk nadzoru nad bankami i nadanie europejskim urzędom nadzoru odpowiedniej roli w tym zakresie to kluczowe warunki ustanowienia unii rynków kapitałowych, a szerzej - zapewnienia harmonijnego funkcjonowania unijnego rynku finansowego jako całości. Można jednak założyć, że dopóki unia bankowa nie zostanie zrealizowana w pełni, a więc pozostawać będzie bez trzeciego filara, jakim jest EDIS, to nie uda się też osiągnąć wszystkich celów unii rynków kapitałowych.

\section{Europejski Fundusz Walutowy jako uzupełnienie unii bankowej}

Projekt rozporządzenia o ustanowieniu Europejskiego Funduszu Walutowego przedstawiony został przez Komisję Europejską 6 grudnia $2017 \mathrm{r}^{44} \mathrm{~W}$ uzasadnieniu wskazała ona, że większość działań pomocowych podjętych w czasie niedawnego kryzysu w strefie euro realizowano w ramach współpracy międzyrządowej, poza unijnymi ramami prawnymi, w szczególności poprzez ESM. Proces

43 A. Janc, Rynki kapitatowe i ich znaczenie dla wzrostu gospodarczego - czy historia może być pouczajaca dla Europy?, [w:] A. Janc, P. Mikołajczak, K. Waliszewski, Europejska Unia Rynków Kapitałowych. Perspektywa finansowania przedsiębiorstw w Polsce, CeDeWu, Warszawa 2015, s. 36-37.

44 Proposal for a Council Regulation on the establishment of the European Monetary Fund, $\operatorname{COM}(2017)$ 827, European Commission, Brussels, 6 XII 2017. 
podejmowania decyzji w ramach takiej współpracy wymaga na ogół przestrzegania czasochłonnych procedur krajowych i dlatego często trudno pogodzić to z potrzebą szybkiego i skutecznego zwalczania kryzysu. Szybsze działania można podejmować w oparciu o procedury unijne. Przekształcenie ESM w EFW włączy ten mechanizm finansowy w unijny system instytucjonalny, w którym nad podejmowanymi decyzjami sprawowane są pełna kontrola sądowa i nadzór Parlamentu Europejskiego, co zapewnia EFW demokratyczną legitymizację. Zgodnie z propozycją Komisji fundusz ten ustanowiono by na bazie obecnych traktatów jako podmiot prawa unijnego, do którego mogłyby przystąpić inne państwa UE po przyjęciu wspólnej waluty. Będąc następcą ESM, przejąlby jego strukturę instytucjonalną i finansową. Fundusz kontynuowałby udzielanie pomocy finansowej potrzebującym jej państwom członkowskim, a nowym elementem byłoby wspomniane już wsparcie finansowe SRF. Wsparcie to mogłoby zostać uruchomione jedynie w przypadku, gdyby zasoby SRF okazały się niewystarczające, by pokryć koszty likwidacji banku lub banków. Miałoby ono formę linii kredytowej lub gwarancji dla SRF i musiałoby zostać spłacone przez sektor bankowy strefy euro. Komisja uznała, że takie wsparcie jest konieczne, by wzmocnić zdolność finansową SRF i zwiększyć zaufanie do systemu bankowego. Decyzje EFW w sprawach pilnych, np. odnośnie do udzielenia wsparcia finansowego dla SRF, nie wymagałyby jednomyślności, ale większości kwalifikowanej wynoszącej 85 proc. głosów. Zasada jednomyślności stosowana byłaby natomiast we wszystkich kluczowych decyzjach finansowych (w tym dotyczących zwiększenia kapitału). Przy zarządzaniu programami pomocy finansowej EFW działałby wspólnie z Komisją Europejską. Zdolność pożyczkowa funduszu powinna wynosić przynajmniej 500 mld euro, co odzwierciedla obecną zdolność pożyczkową ESM. Kraje członkowskie odpowiadałyby za zobowiązania EFW tylko do wysokości swego udziału w kapitale funduszu, a budżet UE nie odpowiadałby za wydatki czy straty EFW w ogóle. Podobnie jak ESM, fundusz ten powinien udzielać swym członkom pożyczek stabilizacyjnych, gdy ich dostęp do finansowania rynkowego zostanie zaburzony. Wsparcie to byłoby jednak obwarowane szeregiem warunków, mających spowodować, by dany kraj spłacił zaciągniętą w EFW pożyczkę. Podobnie jak ESM, poza pożyczkami ogólnymi EFW udzielałby pożyczek m.in. na dokapitalizowanie banków; mógłby także nabywać na rynku pierwotnym i wtórnym obligacje skarbowe danego państwa członkowskiego.

Wsparcie finansowe udzielane przez EFW miałoby na celu głównie ustabilizowanie sektora finansowego i ochronę finansów publicznych przed skutkami wynikłego w tym sektorze kryzysu. Pomoc miałaby być warunkowa, 
a rządy musiałyby negocjować z Komisją Europejską programy dostosowawcze. Ocenia się jednak, że byłyby to działania zbyt późne, bo podejmowane dopiero wtedy, gdy zaistnieją problemy ${ }^{45}$.

Wskazuje się, że udzielanie przez EFW uwarunkowanych pożyczek państwom dotkniętym kryzysem (podobnie jak dotychczas w przypadku EMS) doprowadzi do utrwalenia obecnego systemu, w którym ciężar dostosowań spada głównie na barki tych krajów. Według nich samych jedynym trwałym rozwiązaniem jest kompletna unia fiskalna z prawdziwym budżetem federalnym, tylko on mógłby bowiem stanowić źródło pomocy, gdy poszczególne kraje utracą dostęp do rynku finansowego. Na przykład Stany Zjednoczone nie mogłyby sobie poradzić z niedawnym globalnym kryzysem finansowym bez budżetu federalnego, z którego sfinansowano m.in. programy ratunkowe dla banków czy zwiększoną pomoc dla bezrobotnych. Zadaniem budżetu federalnego byłoby też przeciwdziałanie nierównomiernemu rozwojowi poszczególnych regionów strefy euro. Tylko dzięki niemu można byłoby złagodzić ten problem poprzez finansowanie nowych inwestycji (np. szkoleń i szkół we Włoszech i Portugalii), aby zapewnić bardziej równomierną dystrybucję zdolności produkcyjnych, niezbędną do konwergencji gospodarczej. Bez takich działań różnice w poziomie rozwoju mogą się tylko pogłębić, niosąc poważne konsekwencje społeczne ${ }^{46}$. Zastrzeżenia te wskazują, że nawet powstanie EFW nie zmieni w istotny sposób dotychczasowych możliwości strefy euro $\mathrm{w}$ aspekcie zapobiegania kryzysom finansowym i ich zwalczania.

Oceniając szanse na ustanowienie EFW, warto odwołać się do analizy prawnych i instytucjonalnych uwarunkowań realizacji tego projektu, którą przeprowadziła Alicia Hinarejos z Uniwersytetu w Cambridge. Wynika z niej, że w kontekście celów, które miałby realizować fundusz, bardziej pożądane byłoby powołanie go w ramach porządku prawnego UE, w wyniku dobrze przemyślanej, szerszej reformy traktatu. W praktyce jeszcze przez długi czas nie będzie to jednak możliwe ze względu na fundamentalne spory dotyczące celu i ograniczeń UGW. W tej sytuacji pewnym ograniczonym reformom, uwzględniającym doświadczenia z niedawnego kryzysu finansowego, poddany zostanie $\mathrm{EMS}^{47}$.

45 H. Gabrisch, A fire department...

46 P. Barbieri, S. Vallée, A fiscal union for the eurozone. The only way to save the EU, „Foreign Affairs" [online], 26 IX 2017 [dostęp: 20 I 2018], dostępny w internecie: <https:// www.foreignaffairs.com/articles/europe/2017-09-26/fiscal-union-eurozone>.

47 A. Hinarejos, A possible European Monetary Fund and the future of the euro area, ,Yearbook of European Law" 2019, dostępny w internecie [dostęp: 15 X 2019]: <https://academic.oup.com/yel/advance-article/doi/10.1093/yel/yez003/5529337>. 


\section{Podsumowanie}

Kryzys zadłużenia publicznego w strefie euro uwypuklił słabości konstrukcji, na której ją oparto. Istnieje świadomość, że różnego rodzaju doraźne antykryzysowe działania interwencyjne podejmowane od 2010 r. nie dają gwarancji uniknięcia zagrożeń dla dalszego istnienia tej strefy ze strony przyszłych kryzysów finansowych i gospodarczych. Poszukiwane są zatem rozwiązania systemowe, które miałyby je minimalizować. Zwolennicy federalizmu fiskalnego wskazują na konieczność ustanowienia w strefie euro unii fiskalnej z odrębnym budżetem dla strefy euro. Projekty tego rodzaju, zakładające zwiększenie dotychczasowej skali ponoszenia wspólnego ryzyka i ciężaru długu publicznego, nie mają jednak szans na akceptację wszystkich państw członkowskich. W tej sytuacji jako pragmatyczne rozwiązanie dające możliwość osiągnięcia przynajmniej części celów, którym miałaby służyć unia fiskalna, a w szczególności zapewnienia stabilności strefy euro, może być postrzegana unia bankowa. Zmianą potencjalnie zwiększającą odporność strefy euro na przyszłe kryzysy może być realizowane już wzmocnienie nadzoru nad bankami. $Z$ drugiej strony perspektywa ustanowienia wspólnego systemu gwarantowania depozytów wydaje się dość odległa. Planowane ustanowienie Europejskiego Funduszu Walutowego może zwiększyć możliwości zwalczania kryzysu zadłużenia publicznego dopiero wtedy, gdy taki kryzys już wystąpi. Wszystkie te zmiany nie wymagałyby modyfikowania obowiązujących traktatów, ale stosunkowo ograniczony zakres reform może oznaczać ich mniejszą skuteczność w przypadku kolejnych kryzysów. Unia Europejska, w tym strefa euro, ciągle jest wspólnotą państw o dużym zakresie suwerenności i większość z nich chciałaby takimi pozostać. $\mathrm{Z}$ tego względu w dającej się przewidzieć przyszłości jakiekolwiek maksymalistyczne podejście do reform w strefie euro ma nikłe szanse na realizację. Unijne instytucje i państwa członkowskie będą się koncentrować na rozwiązaniach zwiększających bezpieczeństwo strefy euro i całej Unii Europejskiej, które da się zrealizować w praktyce. Do takich można zaliczyć unię bankową i Europejski Fundusz Walutowy.

\section{Bibliografia}

Asset purchase programmes, „European Central Bank” [online, dostęp: 19 II 2018], dostępny $\mathrm{w}$ internecie: <https://www.ecb.europa.eu/mopo/implement/omt/html/index.en.html . Barbieri P., Vallée S., A fiscal union for the eurozone. The only way to save the $E U$, „Foreign Affairs" [online], 26 IX 2017 [dostęp: 20 I 2018], dostępny w internecie: <https://www. foreignaffairs.com/articles/europe/2017-09-26/fiscal-union-eurozone>. 
Unia bankowa i Europejski Fundusz Walutowy alternatywą dla unii fiskalnej w strefie euro?

Bénassy-Quéré A. i in., Reconciling risk sharing with market discipline. A constructive approach to euro area reform, Centre for Economic Policy Research, styczeń 2018 (CEPR Policy Insight, 91).

Berger H., Dell'Ariccia G., Obstfeld M., Revisiting the economic case for fiscal union in the euro area, International Monetary Fund, Washington, DC, 21 II 2018.

Berschens R., Hildebrand J., Nein, danke. Austria's compromise on European deposit insurance irritates Berlin, „Handelsblatt” [online], 13 IX 2018 [dostęp: 13 X 2019], dostępny w internecie: $<$ https://www.handelsblatt.com/today/finance/nein-danke-austrias-compromiseon-european-deposit-insurance-irritates-berlin/23583320.html?ticket=ST-33407237oPYtyuGbaEboedrbkrKd-ap2>.

Brooks J.R., Fiscal federalism as risk-sharing. The insurance role of redistributive taxation, Georgetown University Law Center, 2014, dostępny w internecie [dostęp: 12 XI 2017]: <http://scholarship.law.georgetown.edu/cgi/viewcontent.cgi?article=2357\& context $=$ facpub $>$.

Brunsden J., Germany stands firm against EU bank deposit guarantee plan, „Financial Times” [online], 11 X 2017 [dostęp: 3 III 2018], dostępny w internecie: <https://www.ft.com/ content/58c9a172-ae7d-11e7-beba-5521c713abf4>.

Capital Markets Union: progress on building a single market for capital for a strong Economic and Monetary Union, $\operatorname{COM(2019)~} 136$ final, European Commission, Brussels, 15 III 2019, dostępny w internecie [dostęp: 12 X 2019]: <https://ec.europa.eu/finance/docs/ policy/190315-cmu-communication_en.pdf $>$.

Communication to the European Parliament, the Council, the European Central Bank, the European Economic and Social Committee and Committee of the Regions on completing the Banking Union, COM(2017) 592 final, European Commission, Brussels, 11 X 2017.

Cózar M.M., The only feasible fiscal union for the euro area, „European View”, 17 V 2017.

Dreyer J.K., Schmid P.A., Fiscal federalism in monetary unions. Hypothetical fiscal transfers within the Euro-zone, „International Review of Applied Economics” 2015, vol. 29, issue 4.

Dyrektywa Parlamentu Europejskiego i Rady 2014/49/UE z dnia 16 kwietnia 2014 r. w sprawie systemów gwarancji depozytów, Dz. Urz. UE L 173, 12 VI 2014.

Eichengreen B., The euro's narrow path, „Project Syndicate” [online], 11 IX 2017 [dostęp: 11 II 2018], dostępny w internecie: <https://www.project-syndicate.org/commentary/euro-narrow-path-france-germany-cooperation-by-barry-eichengreen-2017-09? barrier=accesspaylog $>$.

Une Europe qui protège les Européens, „En Marche!” [online, dostęp: 6 IX 2017], dostępny w internecie: $<$ https://en-marche.fr/emmanuel-macron/le-programme/europe $>$.

Europejska Unia Bankowa, red. M. Zaleska, Difin, Warszawa 2015.

The fiscal impact of financial sector support during the crisis, „ECB Economic Bulletin” 2015, issue 6.

Gabrisch H., A fire department for the Euro area. Reflections on a fiscal risk-sharing capacity, Munich Personal RePEc Archive, 18 I 2018 (MPRA Paper, 83965).

Genschel P., Jachtenfuchs M., From market integration to core state powers. The Eurozone crisis, the refugee crisis and integration theory, „Journal of Common Market Studies” 2018, vol. 56, No. 1, s. 178-196.

Hinarejos A., A possible European Monetary Fund and the future of the euro area, „Yearbook of European Law" 2019, dostępny w internecie [dostęp: 15 X 2019]: <https://academic. oup.com/yel/advance-article/doi/10.1093/yel/yez003/5529337>. 
Horobin W., Macron pushes Germany to commit more to Eurozone, „Wall Street Journal” [online], 13 VII 2017 [dostęp: 9 I 2018], dostępny w internecie: <https://www.wsj.com/ articles/macron-pushes-germany-to-commit-more-to-eurozone-1499946041>.

Howarth D., Quaglia L., The difficult construction of a European Deposit Insurance Scheme: a step too far in Banking Union?, „Journal of Economic Policy Reform” 2018, No. 21, issue 3.

Janc A., Rynki kapitatowe i ich znaczenie dla wzrostu gospodarczego - czy historia może być pouczająca dla Europy?, [w:] A. Janc, P. Mikołajczak, K. Waliszewski, Europejska Unia Rynków Kapitałowych. Perspektywa finansowania przedsiębiorstw w Polsce, CeDeWu, Warszawa 2015.

Jokivuolle E., Pennacch G. G., How to design the European Deposit Insurance Scheme, „Vox” [online], 31 V 2019 [dostęp: 16 X 2019], dostępny w internecie: <https://voxeu.org/article/ how-design-european-deposit-insurance-scheme>.

Juncker J.-C., Dokończenie budowy europejskiej Unii Gospodarczej i Walutowej, Komisja Europejska, 22 VI 2015, dostępny w internecie [dostęp: 6 IX 2017]: <https://ec.europa. $\mathrm{eu} /$ commission/sites/beta-political/files/5-presidents-report_pl.pdf $>$.

Jurkowska-Zeidler A., Europejski System Gwarantowania Depozytów: trzeci brakująy filar do dokończenia Unii Bankowej, „Annales Universitatis Mariae Curie-Skłodowska. Sectio H" 2016, vol. 50, No. 4.

Key excerpts: Mario Draghi says ECB 'Ready to do whatever it takes', „The Wall Street Journal" [online], 26 VII 2012 [dostęp: 21 VII 2019], dostępny w internecie: <https:// blogs.wsj.com/economics/2012/07/26/key-excerpts-mario-draghi-says-ecb-ready-to-dowhatever-it-takes/>.

Konkluzje - 13-14 XII 2012 r., EUCO 205/12, Rada Europejska, Bruksela, 14 XII 2012, dostępne w internecie [dostęp: 6 IX 2017]: <https://www.consilium.europa.eu/uedocs/cms data/docs/pressdata/PL/ec/134361.pdf $>$.

Micossi S., A blueprint for completing the Banking Union, CEPS, [Brussels] 2017 (Policy Insights, 2017/42).

Münchau W., Macron's fiscal union points the way for Euro-Bonds, „Financial Times”, 22 V 2017. Oręziak L., Rynek finansowy Unii Europejskiej, Twigger, Warszawa 1999.

Plan działania na rzecz tworzenia unii rynków kapitałowych, COM(2015) 468 final, Komisja Europejska, Bruksela, 30 IX 2015.

Proposal for a Council Regulation on the establishment of the European Monetary Fund, $\operatorname{COM}(2017)$ 827, European Commission, Brussels, 6 XII 2017.

Report of the Study Group on the role of the public finance in European integration, Commission of the European Communities, Brussels, April 1977 [raport McDougalla], dostępny w internecie [dostęp: 1 III 2018]: <http://ec.europa.eu/archives/emu_history/documentation/ chapter8/19770401en73macdougallrepvol1.pdf $>$.

Report on economic and monetary union in the Community, Committee for the Study of Economic and Monetary Union, June 1989 [raport Delors'a], dostępny w internecie [dostęp: 25 II 2018]: <http://ec.europa.eu/economy_finance/publications/pages/publication6161_en.pdf>.

Report to the Council and the Commission on the realization by stages of economic and monetary union in the Community, Luxembourg, 8 X 1970, dostępny w internecie [dostęp: 6 III 2018]: <http://ec.europa.eu/archives/emu_history/documentation/chapter5/19701008en72realisationbystage.pdf $>$. 
Unia bankowa i Europejski Fundusz Walutowy alternatywą dla unii fiskalnej w strefie euro?

Rodrik D., Can Macron pull it off?, „Project Sindicate” [online], 9 V 2017 [dostęp: 27 VIII 2018], dostępny w internecie: $<$ https://www.project-syndicate.org/commentary/macron-germanyeurozone-fiscal-union-by-dani-rodrik-2017-05?barrier=accesspaylog $>$.

Schmidt Ch.M., How to renew the European project, „Project Sindicate” [online], 1 IX 2017 [dostęp: 27 X 2017], dostępny w internecie: <https://www.project-syndicate.org/ commentary/european-integration-france-germany-by-christoph-m--schmidt-201709? barrier=accesspaylog $>$.

Sinn H.W., How to start paying off southern Europe's debts, „The Guardian” [online], 29 I 2018 [dostęp: 12 II 2018], dostępny w internecie: <https:/www.theguardian.com/business/2018/ jan/29/how-to-start-paying-off-southern-europes-debts $>$.

Thirion G., European Fiscal Union: Economic rationale and design challenges, CEPS, [Brussels] 2017 (Working Document, 2017/01).

Tsakalotos E., Banking union is not enough to save the eurozone, „Financial Times” [online], 7 I 2018 [dostęp: 11 II 2018], dostępny w internecie: <https://www.ft.com/ content/0096a770-f225-11e7-bb7d-c3edfe974e9f>.

Van Rompuy H., W kierunku faktycznej unii gospodarczej i walutowej, 5 XII 2012, dostępny w internecie [dostęp: 17 X 2019]: <https://www.consilium.europa.eu/media/23809/134201.pdf>.

W kierunku faktycznej unii gospodarczej $i$ walutowej. Sprawozdanie przewodniczacego Rady Europejskiej Hermana Van Rompuya, Bruksela, 26 VI 2012, dostępne w internecie [dostęp: 17 X 2019]: <https://www.consilium.europa.eu/uedocs/cms_data/docs/pressdata/PL/ ec/131295.pdf $>$.

Waliszewski K., Europejski System Gwarantowania Depozytów jako trzeci element Unii Bankowej, „Bezpieczny Bank” 2016, nr 1 (62).

Wniosek Rozporzadzenie Parlamentu Europejskiego i Rady zmieniające rozporzadzenie (UE) $n r$ 806/2014 w celu ustanowienia europejskiego systemu gwarantowania depozytów, COM(2015) 586 final, Komisja Europejska, Strasburg, 24 XI 2015.

Wolff G.B., Eurozone or EU budget? Confronting a complex political question, „Bruegel” [online], 29 VI 2017 [dostęp: 27 VIII 2017], dostępny w internecie: <https://bruegel. org/2017/06/eurozone-or-eu-budget-confronting-a-complex-political-question/>.

Zaleska M., Zintegrowane ramy finansowe - koncepcja i wyzwania, [w:] Europejska Unia Bankowa, red. M. Zaleska, Difin, Warszawa 2015. 